\title{
URBANISTIKOS PAVELDO IŠSAUGOJIMO TEISINĖS PRIELAIDOS LIETUVOJE
}

\author{
Jūratė Jurevičienè \\ Architektūros pagrindu ir teorijos katedra, Vilniaus Gedimino technikos universitetas, \\ Pylimo g. 26/Trakųg. 1, LT-01132 Vilnius, Lietuva \\ El.paštasarchpit@ar.vgtu.lt \\ Iteikta 20081222
}

\begin{abstract}
Santrauka. Nagrinejjamos dabarties Lietuvoje susiklosčiusios teisinės paskatos ir kliūtys išsaugoti urbanistikos paveldą. Analizuojami Lietuvos ịstatymai ir ịstatymų igyvendinamieji dokumentai, reglamentuojantys urbanistikos paveldo vietovių apsaugą kultūros paveldo apskaitos bei teritorijų planavimo lygmenyse. Siekiama atskleisti urbanistinių darinių vertingųjų savybių išsaugojimo teisinių nuostatų veiksmingumą. Atskleidžiami teisiniai trukdžiai ir paskatos gyventojams dalyvauti istorinių miestų ir miestelių kultūrinès vertès išsaugojimo procesuose.
\end{abstract}

Reikšminiai žodžiai: urbanistikos paveldas, kultūros paveldo apskaita, teritorijų planavimas, visuomenė.

\section{Ivadas}

Išsaugoti urbanistikos vertybes, jas atgaivinti ir stiprinti jų reikšmę visuomenejje neabejotinai galima tik tuomet, kai valstybė sukuria tam palankias teisines prielaidas. Urbanistiniai dariniai ir kultūrinis kraštovaizdis yra sudètingiausi paveldo objektai, kurių apsauga reikalauja, kad pastangas ir finansinius išteklius sutelktų statiniu ir sklypų savininkai, savivaldybių ir valstybès institucijos. Todèl kiekvienoje šalyje susiklosčiusios teisès aktų sistemos darna tampa lemiančiu veiksniu, nuo kurio priklauso, ar bus išsaugotos vertingosios senųjų miestų ir miestelių savybès.

Pastaraisiais metais didžiųjų Lietuvos miestų istoriniai centrai, kuriems suteiktas valstybès saugomų objektų statusas, patyrè didžiausią statybų plètros poveikį. Šie pokyčiai sukèlè aštrias diskusijas ịvairiuose lygmenyse, buvo parengta daug ekspertizių ir teritorijų planavimo dokumentų igyvendinamų ir planuojamų statybų poveikiui pagrịsti, tačiau Lietuvos urbanistikos paveldo apsaugą reglamentuojančių îstatymų reikalavimai išliko neapibrèžti ir prieštaringi, palyginti su reikalavimais, galiojančiais, pavyzdžiui, archeologinėms vietovèms. Dabartiniu laikotarpiu Lietuvos kultūros paveldo apsaugą administruojančiųų institucijų yra kaip niekad daug, tačiau jų atsakomybė nepakankamai apibrèžta, urbanistikos paveldo vertingosios savybès nèra nustatytos arba neivertinti per kelerius pastaruosius metus ịvykę jų pokyčiai (pavyzdžiui, Vilniaus senamiesčio apsaugos reglamente, patvirtintame $2003 \mathrm{~m}$., gausu ne tik neapibrèžtumų, bet reglamento sąvokos neatitinka LR Nekilnojamojo kultūros paveldo apsaugos ịstatymo, patvirtinto $2004 \mathrm{~m}$.).

Straipsnyje siekiama atskleisti Lietuvos urbanistikos paveldo apsaugos trukdžius svarbiausiųjų šią sriț reglamentuojančių teisès aktų aspektu.

\section{Urbanistikos paveldo apskaita}

Urbanistikos paveldo samprata ir jo teisinè apsauga Lietuvoje plètojosi palaipsniui, apimdama vis daugiau teritorinių objektų. Vilniaus senamiestis senovès paminklu buvo pripažintas jau praejjusio amžiaus tarpukaryje, 1947 m. jis buvo įtrauktas ị SSSR Architektūros reikalų komiteto paskelbtą 20 saugotinų istorinių miestų sąrašą. $1963 \mathrm{~m}$. buvo patvirtintas saugomų Lietuvos senamiesčių respublikinès reikšmès urbanistikos paminklų sąrašas (Glemža 2000). XX a. šeštajame ir septintajame dešimtmečiuose atlikus Lietuvos urbanistikos paveldo tyrimus, 61 miestas bei miestelis buvo 
pripažintas vertingu ir paskelbtas vietinès reikšmès urbanistikos paminklu. $1985 \mathrm{~m}$. prie jų priskirtas dar vienas ir paskelbti jų vertinimo duomenys: raida, būdingi bruožai, saugotini elementai bei formos. Tyrimams vadovavusio Algimanto Miškinio vertinimu, iš $1940 \mathrm{~m}$. Lietuvos teritorijoje sąlygiškai buvusių miesto pobūdžio gyvenviečių 287 gali būti priskiriamos urbanistikos paveldui (Miškinis 2003).

Pagal Nekilnojamojo kultūros paveldo apsaugos įstatymą, kultūros paveldo objektais laikomi tik objektai, ịtraukti ị Kultūros vertybių registrą (toliau - Registrą). Jiems taikoma laikinoji apsauga, Registro objektus LR kultūros ministras skelbia saugomais valstybès, nacionalinès reikšmès kultūros paveldo objektus skelbia kultūros paminklais. Kultūros paveldo departamento duomenimis, $2007 \mathrm{~m}$. kultūros paveldo objektų, paskelbtų valstybès saugomais Lietuvoje, buvo 6028, kultūros paveldo objektų, paskelbtų paminklais, - 1073, kultūros paveldo objektų, paskelbtų savivaldybès saugomais, nebuvo (Kultūros paveldo departamento prie LR kultūros ministerijos $2007 \mathrm{~m}$. veiklos ataskaita).

Tačiau didelè dalis savitų ilgalaikèje raidoje susiklosčiusių Lietuvos urbanistinių darinių iki šiol nèra registruoti LR Kultūros vertybių registre. Pavyzdžiui, $1999 \mathrm{~m}$. buvo nustatytos Molètų miesto centro istorinès dalies vertingosios savybès, saugotina teritorija ir jų apsaugai pasiūlytas savivaldybių reikšmės kultūros vertybès statusas (Miškinis 2003), tačiau i Registrą objektas iki šiol neįtrauktas. Nekilnojamojo kultūros paveldo apsaugos istatyme yra numatytos galimybès savivaldybèms iteisinti savo registrus, tačiau menki ju biudžetai tampa kliūtimi su registrais prisiimti ir saugojimo išlaidų naštą. Todèl daugeliui savitų istorinių miestelių Lietuvoje iki šiol nesuteikta teisinè apsauga. Didelè dalis šių vietovių pasižymi vaizdinga gamtine aplinka, gamtos ir kultūros paveldo integralumu. Raiškus pavyzdys yra šiaurinè Naujosios Vilnios dalis. Šiaurinèje jos dalyje yra ịspūdingas Vilnios slènio šlaitų kraštovaizdis ir XX a. pradžios medinio užstatymo teritorija. Panoraminiai vietovès vaizdai ir siluetai čia išliko daugiaplaniai, struktūrizuoti, autentiški, estetiškai vertingi, tačiau ị Registrą tèra ịrašyti tik keli pavieniai Naujosios Vilnios pastatai. Dalis urbanistikos paveldo objektų, tebesančių Registre, dèl aplinkos vertę menkinančių naujųjų statybų, ilgą laiką nevykdytos senųjų statinių priežiūros yra praradę buvusias vertingąsias savybes ir tèra saugomi nominaliai.

Pagal Nekilnojamojo kultūros paveldo apsaugos įstatymą buvo parengta nauja tipologinè Registro struktūra. Dabar jị sudaro pavieniai objektai, kompleksai ir vietovès. Vietovių sąraše - senamiesčiai, miestų ir miestelių istorinès dalys, miestų parkai (Vingio parkas Vilniuje, Ąžuolyno parkas Kaune ir kt.), etnografinès kaimo gyvenvietes ir jų dalys. Iki $2005 \mathrm{~m}$. ne tik senamiesčiai ir istoriniai miestų centrai, bet ir dalis pastatų ansamblių (pavyzdžiui, namų kompleksas Vilniuje tarp T. Kosciuškos, Olandų ir V. Dobužinskio gatvių) bei etnografinès kaimų gyvenvietès ir jų dalys buvo skiriami urbanistikos paveldui.

Reikšmingiausios Vilniaus urbanistikos paveldo vertybès - Senamiestis bei buvusių istorinių priemiesčių - Naujamiesčio, Žvèryno, Šnipiškių, Paupio, Užupio ir Antakalnio - teritorijų dalys. Tačiau Registre Vilniaus urbanistikos paveldą sudaro ir buvę Lazdynų bei Žirmūnų mikrorajonai, statinių kompleksai Gedimino prospekte (Seimo I-ųjų rūmų, buvusių Profsąjungų rūmų ir Teisingumo ministerijos pastatų), Ukmergès gatvèje (vadinamasis Visuomeninis miesto centras dešiniajame Neries krante), Saulètekio alèjoje (trys mokomųjų korpusų pastatai). Akivaizdu, kad šie objektai yra praradę pirmines erdvių ir tūrių sandaros, medžiagiškumo, aplinkos ir netgi paskirties savybes. Nauji šių urbanistinių darinių elementai, netgi pastarajame dešimtmetyje juose atsiradusios naujos urbanistinès dominantès buvo planuojamos ir vykdomos be kultūros paveldo apsaugos institucijų žinios.

Lietuvos urbanistikos paveldo objektų visuma nesudarys darnios vertybių sistemos, kol nebus nustatyta, kokie sovietinio laikotarpio objektai laikytini vertingais ir saugotinais. Pernai metais Kultūros paveldo departamento užsakymu pradèti rengti sovietinio laikotarpio išskirtinių (pagal preliminarų sąrašą) architektūros objektų apskaitos duomenys, tačiau šie darbai negali kompensuoti urbanistikos paveldo fundamentiniu tyrimų trūkumo. Tai, kad urbanistikai vertinti būtini įvairiapusiai tyrimai, tačiau nèra parengta netgi Vilniaus senamiesčio architektūrinès meninès sandaros specialiųjų mokslinių studijų, pabrèžia Rimantas Buivydas. Jis pažymi, kad kultūrinès vertès neištirtumas lemia ir socialines psichologines pasekmes - tai daro "Senamiesčio architektūrinị „tekstą" suvokiamą kaip nerišlų“ (Buivydas 2004).

\section{Urbanistikos paveldo apsauga teritorijų planavimo srityje}

Nekilnojamojo kultūros paveldo apsaugos specialiojo teritorijų planavimo dokumentu rengimo taisyklès, patvirtintos $2005 \mathrm{~m}$., nurodo, kad saugomų objektų paveldosaugos reikalavimai nustatomi specialiaisiais 
apsaugos planais. Tačiau Miestų ir miestelių bendrųjų planų rengimo taisykless, patvirtintos $2004 \mathrm{~m}$. (nauja redakcija $2006 \mathrm{~m}$.), numato, kad urbanistikos paveldo apsauga reglamentuojama ir teritorijų bendrojo planavimo priemonèmis. Šios taisyklès nurodo, kad keletas iš bendrojo plano uždavinių - numatyti priemones, užtikrinančias kultūros paveldo objektų išsaugojimą, pateikti paminklosauginių teritorijos naudojimo apribojimų pasiūlymus sukuriant koncepciją, nustatyti saugomų kultūros paveldo objektų naudojimo reglamentus konkretizuojant sprendinius. Jau Vilniaus miesto bendrajame plane iki 2005 m., patvirtintame 1998 m., buvo parengti nekilnojamojo kultūros paveldo apskaitos, tvarkybos, naudojimo, prioritetinio saugojimo finansavimo siūlymai. Nors patvirtintas teritorijos bendrasis planas laikytinas ístatymu, dauguma Vilniaus miesto bendrojo plano kultūros paveldo apsaugos sprendinių nebuvo igyvendinta.

Teritorijų planavimas dabarties laikmečiu Lietuvoje dažnai tèra tapęs biurokratinių procedūrų rinkiniu. Kadangi Kultūros paveldo apsaugos specialiojo planavimo taisyklès vienareikšmiškai nurodo, kad saugomų kultūros paveldo objektų teritorijos ir apsaugos zonos nustatomos specialiuoju planavimu, Kultūros paveldo departamentas užsakè parengti keliolikos miestų ir miestelių istorinių centrų bei kitų saugomų vietovių ir kompleksų apsaugos specialiuosius planus. Tačiau Nekilnojamojo kultūros paveldo apsaugos ịstatymo 8 str. 5 dalis nurodo, kad kultūros paveldo objektų ar vietovių teritorijų ribas apibrèžia nekilnojamojo kultūros paveldo vertinimo tarybos, t. y. ribos nustatomos vertybès registravimo etape. Urbanistikos vertybiu sudèties ir apimties bei vertingujų elementų nustatymo metodikoje, patvirtintoje Kultūros paveldo centro direktoriaus 20011116 įsakymu Nr. 127, numatoma, kad registruotos urbanistinès vietovès teritorijos ribos gali būti koreguojamos, nustačius urbanistikos vertybès apimti jos apskaitos dokumentu rengimo etape. Skubiai parengtos apskričiu ir savivaldybiu kultūros paveldo tinklu schemos, kuriose pateikiami esami registruotu kultūros paveldo objektų sąrašai ir jų teritorijų ribų koordinatès nesiūlant sprendinių, todèl vargu ar šie specialieji planai gali būti laikomi teritorijų planavimo dokumentais. Atskiri specialieji planai rengiami net tų pačių vietovių apsaugos zonų riboms ir jų apsaugos reglamentams nustatyti. Apsaugos specialusis planavimas iki šiol netapo veiksminga urbanistikos paveldo apsaugos priemone.

Tiek Nekilnojamojo kultūros paveldo apsaugos, tiek Saugomų teritorijų įstatymai, skirti vietovių kultūrinei vertei išsaugoti, reikalauja steigti draustinị. Draustinius urbanistinèms vietovems išsaugoti numatoma steigti ir daugumos apskričių teritorijų bendrųjų planų sprendiniuose (LR Valstybinès kultūros paveldo komisijos sprendimas 2008). Tačiau urbanistiniai draustiniai tera ikkurti saugoti istoriniams miesteliams, esantiems nacionaliniuose ir regioniniuose parkuose. Šių parku vietovèms, įrašytoms ị Registrą, taikomi Aplinkos ministerijos ir Kultūros ministerijos reikalavimai. Dviguba apsauga skatina saugojimo darbų kompleksiškumą ir tęstinumą. Pavyzdžiui, Trakų istorinio nacionalinio parko urbanistiniame draustinyje $2007 \mathrm{~m}$. Karaimų gatvès dalis buvo rekonstruota Europos Sąjungos struktūrinių fondų ir Trakų savivaldybės lëšomis. Projektas buvo parengtas kaip Trakų senamiesčio kompleksinès tvarkybos, vykstančios jau keliasdešimt metų, etapas.

Daugelyje kitų registruotų urbanistinių vietovių, nepaskelbtų saugomomis, apsiribojama pavienių kultūros paveldo statinių ir ansamblių arba pagrindinių viešųjų erdvių istoriniuose centruose tvarkyba. Didesnès investicijos telkiamos tik į prekybos centrų statybą, dažniausiai žalojančią susiklosčiusią urbanistinę struktūrą. Ir bloga urbanistinio audinio fizinè būklè, ir jo autentiškumas tampa būdingais tik nuošaliausiųjų Lietuvos istorinių miestelių bruožais (žr. pav.).

Dažnai pripažįstama, kad viena silpniausių Lietuvos urbanistikos paveldo apsaugos grandžių yra stebėsena (monitoringas). Baltijos jūros šalių kultūros ministrai savo susitikime, surengtame Švedijos kultūros ministro iniciatyva $1997 \mathrm{~m}$. Liubeke, nusprendè sukurti regiono kultūros paveldo stebėsenos grupę, kurioje dirbtų ir Lietuvos atstovai. Šios grupés darbo tikslas - derinti šalių kultūros paveldo apsaugos teisès aktų reikalavimus. Tačiau Lietuvoje sisteminė urbanistikos paveldo vietovių stebėsena iki šiol nèra vykdoma. Dažnai teritorijų planavimo specialistams tenka patiems nustatyti, kaip ir kiek keičiasi vertingosios vietovių savybès, kokie veiksniai lemia pokyčius. Nevykdoma ir apsaugos teisès aktu, kurie nuolat keičiasi ir papildomi naujais straipsniais, veiksmingumo stebèsena, reikalinga urbanistikos paveldo apsaugos dokumentu rengejams. Numatyta parengti ir patvirtinti saugomu architektūrinio pobūdžio kultūros paveldo objektų (nesančių valstybiniuose parkuose ar valstybiniuose rezervatuose) teritorijų ir jų apsaugos zonų stebėsenos programą (Dèl Lietuvos Respublikos architektūros politikos krypčių igyvendinimo 2006-2010 metų priemonių patvirtinimo 2006). Numatoma, kad bus parengta ir kultūros ministro patvirtinta Architektūrinio pobūdžio kultūros paveldo objektų teritorijų ir jų apsaugos zonų stebèsenos 


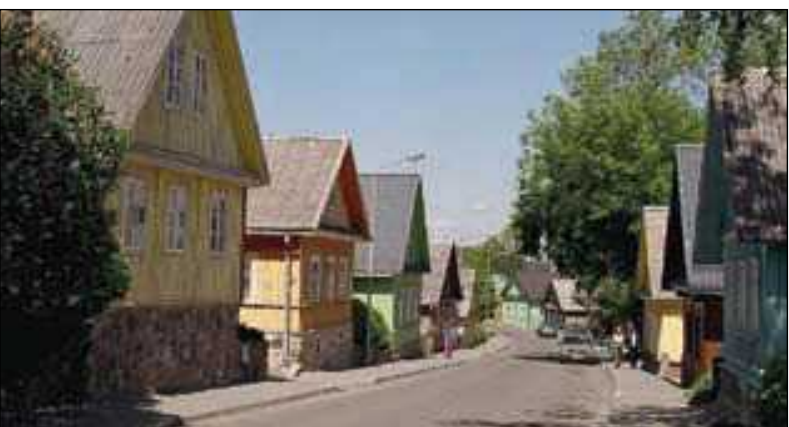

1

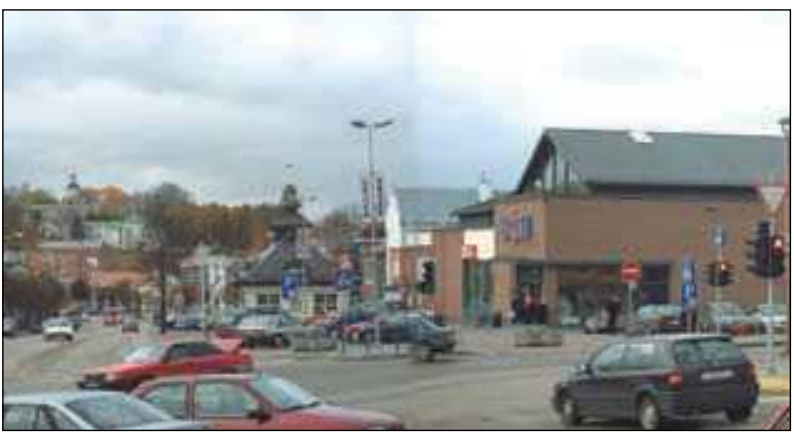

3

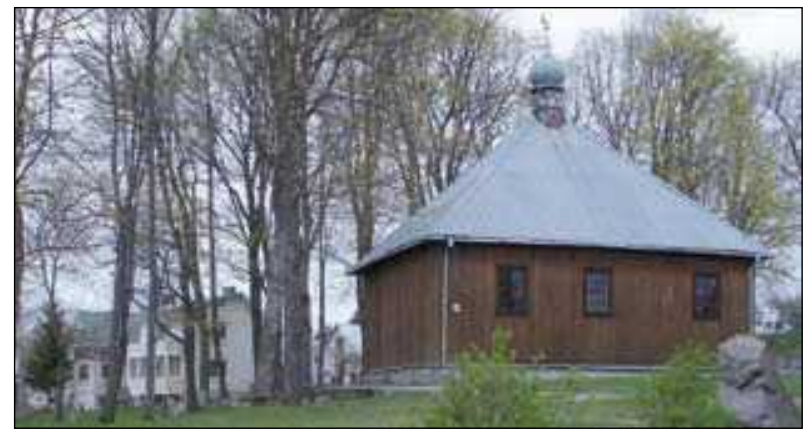

2

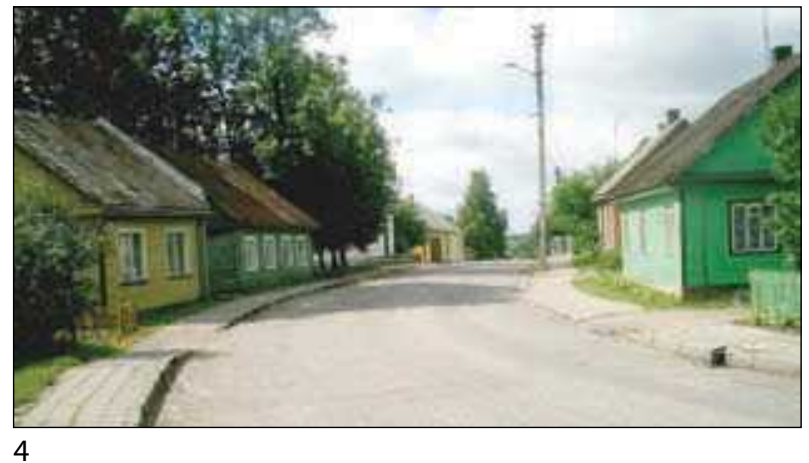

Urbanistikos paveldo autentiškumo lygmuo: 1 - Karaimu gatvė Trakų senamiestyje; 2 - Totorių mečetè ir senosios kapinės Keturiasdešimties Totorių kaime Vilniaus rajone; 3 - prekybos centras „Maxima“ Telšių senamiestyje; 4 - Vytauto gatvė Daugy istoriniame centre Alytaus rajone

Level of authenticity of urban heritage: 1 - Karaimai street in the old town of Trakai; 2 - the Mosque of the Tatars and the Old Cemetery in the village of Keturiasdešimties Totorių; 3 - "Maxima" commercial center in the old town of Telšiai; 4 - Vytautas street in the historic center of Daugai

programa, skirta šių objektų ir jų apsaugos zonų būklei sistemingai stebèti, jų komponentų būklei ir tarpusavio sąveikai analizuoti, antropogeniniam poveikiui vertinti ir prognozuoti. Igyvendinus šiuos planus galima tikètis daug veiksmingesnio urbanistikos paveldo saugojimo naudojant teritorijų planavimo priemones.

\section{Visuomenès dalyvavimas saugant urbanistikos paveldą}

Urbanistikos paveldas neatskiriamas nuo bendruomenès. Žymus Škotijos paveldosaugininkas ir miestų planuotojas Dennis Rodwell'as savo pranešime Vilniaus savivaldybès, UNESCO Lietuvos nacionalinès komisijos ir Kultūros paveldo departamento surengtoje regioninejje konferencijoje Vilniuje $2003 \mathrm{~m}$. liepą. 1-3 dienomis pabrèžè, kad darni istorinių miestų plètra priklauso nuo ryšio tarp vietos ir žmonių, nuo teritorinio paveldo integracijos ị visuomenès gyvenimą ir nuo visuomenès integracijos ị vietovę.

Lyginant Lietuvos ir kitų Europos Sajungos šalių urbanistikos paveldo apskaitos reikalavimus, akivaizdu, kad skirtingai traktuojamas vietos bendruomenems tenkantis vaidmuo. Lietuvoje apibrèžta, kas gali teikti siūlymus Registrui - Nekilnojamojo kultūros paveldo apsaugos įstatymo $8 \mathrm{str} .4$ dalis nurodo, kad „tradicinès religinès bendruomenès, bendrijos ir centrai, mokslo ir studijų bei kitos valstybinès tyrimų institucijos gali organizuoti jų veiklos sriti atitinkančio ar nuosavybès teise turimo kultūros paveldo inventorizavimą ir atskleidimą, savo veiksmus derindamos su Departamentu“. Pavyzdžiui, Danijoje kiekvienas gyventojas gali siūlyti Danijos paveldo agentūrai bet kurị pastatą îtraukti $\mathfrak{i}$ vertybių registrą. Paveldo agentūra privalo patikrinti, ar siūlomas objektas atitinka nustatytus vertès kriterijus (pastatus registrui ji gali siūlyti ir savo iniciatyva). Jei Paveldo agentūra ịvertina, kad objektas vertas vertybès statuso, arba nustato, kad registruotas objektas neteko kultūrinès vertès (sudegè, yra perstatytas ir pan.), ji privalo konsultuotis su visuomene. Per tris mènesius bet kuris asmuo, visuomeninè institucija ar valdžios ìstaiga gali pareikšti savo nuomonę (Listing. Historic buildings ... 2008), kurią ịvertinus galutinị sprendimą priima Danijos kultūros ministerija. 
Lietuvoje rengiant visų lygmenų: bendrojo, specialiojo ir detaliojo, teritorijų planus yra numatytos pristatymo visuomenei, atsiliepimų surinkimo, atsakymu rengimo, koregavimo pagal pastabas procedūros. Ši nuostata atitinka bendruosius Europos Sąungos teritorijų planavimo reikalavimus, gyventojai aktyviai dalyvauja svarstant detaliųjų planų sprendinius. Tačiau teisinės galimybès dalyvauti urbanistikos paveldo apsaugos projektuose yra daug menkesnès nei daugelyje kitų Europos Sąungos šalių. Pavyzdžiui, Švedijoje rengdami saugomų miestelių regeneravimo (atnaujinimo) projektus planuotojai didžiąją laiko dalį praleidžia bendraudami su vietos gyventojais, aiškindamiesi jų požiūri i vertybes ir aplinkos kokybès sampratą, diskutuodami, kokie svarbiausi vietos savitumo požymiai ir saugotini elementai (Westerlind 2005). Numatomuose pertvarkyti kvartaluose netgi dažnai ịsteigiamos visą planavimo laiką veikiančios viešos projektų aptarimo vietos.

Nestabdomai vykstant Lietuvos miestelių dezurbanizacijai, juose sparčiausiai mažéja socialiai aktyviausių jaunesniųjų gyventojų skaičius. Viešosiose diskusijose dažnai pritariama, kad pastaraisiais metais urbanistikos paveldo apsauga tampa įdomi tik nedaugeliui specialistų ir vienam kitam vietos entuziastui (nors ir nepateikiama šią nuomonę pagrindžiančių sociologinių tyrimų duomenų). Visuomenès pokyčiai Lietuvos urbanistikos paveldo objektų apsaugos srityje dažnai ignoruojami. Neịvertinama, kad svarbu juos analizuoti, ieškoti teisinių galimybių naujai atsiradusioms kliūtims ịveikti. Pavyzdžiui, taip pat dèl mažẻjančio gyventojų skaičiaus bei miesto pakraščiuose pastatytų prekybos centrų, žlugdančių tradicines parduotuvèles, grèsmè kilo unikalaus Pasaulio paveldo objekto - Kvedlinburgo, esančio Vokietijos rytinejje dalyje, viduramžiškam miesto centrui išlikti. Tačiau jau netrukus, susivienijus Vokietijai, buvo analizuotos kultūrinei vertei kylančios grèsmès ir parengta strategija joms išvengti. Daugelis senuju Kvedlinburgo pastatu, kuriuos buvo planuota griauti, buvo sutvirtinti ir restauruoti Vokietijos Federalinès vyriausybės fondų lèšomis. Sutelktomis paveldosaugininkų pastangomis istorinis Kvedlinburgo centras nuosekliai tvarkomas ir pritaikomas pagal šiuolaikinę paskirtį, nežalojant paveldo (World Heritage Site Quedlinburg 2004).

Neigiamų vidaus ir išorès teisinių, ekonominių, socialinių itampų kontekste dažnai netiketai atsiskleidžia teigiamas subjektyvusis Lietuvos urbanistikos paveldo apsaugos veiksnys. Pavyzdžiui, Plungejje buvo ¡kurtas pirmasis Lietuvoje regioninis kultūros centras Žemaičių dailès muziejus. Jam pritaikyta miesto centrą formuojanti dvaro sodyba. Gavus paramą iš Europos Sąjungos struktūrinių fondų ir savivaldybei prisidedant 2006-2008 m. ígyvendintas projektas „Plungès M. Oginskio dvaro sodybos pritaikymas turizmo reikmèms“. Plungès miesto ir Telšių teritorinio padalinio paveldosaugininkai sugebèjo apginti sodybos teritorini vientisumą, ǐšaugoti ją nuo statybų, nesusijusių su dvaro sodybai būdingomis paskirtimis. Finansinè Europos Sąjungos struktūrinių fondų parama taip pat buvo panaudota atkurti, restauruoti ir viešajai turizmo infrastruktūrai pritaikyti Kurtuvenų miestelyje esančios dvaro sodybos pastatams, sutvarkyti dvaro parkui. Projektas parengtas Kurtuvenų regioninio parko administracijos iniciatyva.

Kultūrine istorine verte pasižyminti miesto aplinka siejama su išskirtiniu socialiniu statusu, prestižu, tačiau dažnai - su tiesiogine finansine nauda. Rengiant naujos statybos ar rekonstrukcijos projektus, ne tik privačiu savininkų komercinis noras igyti kuo didesnio tūrio pastatą, bet ir teisinès galimybès diktuoti architektams savo estetinę sampratą dažnai nugali viešąji paveldosauginį interesą - teikti pirmenybę susiklosčiusioms kultūrinèms vertybèms. Tačiau vilties teikia pastaraisiais metais pagaliau pradètas igyvendinti investicijų $i$ kultūros paveldo objektų tvarkybos darbus, jei objektai yra prieinami visuomenei, grąžinimo mechanizmas, panašus ị jau ilgą laiką veikiantị senosiose ES šalyse.

\section{Išvados}

1. Lietuvos urbanistikos paveldo apsaugos teisinès prielaidos nesudaro nuoseklios ir pakankamai sistemiškos teisinès bazès, reikalingos veiksmingai urbanistikos paveldo objektų tvarkybai. Didelei daliai vertingų istorinių miestelių ir jų dalių iki šiol nèra skirta teisinè apsauga.

2. Dalis urbanistikos paveldo apsaugos teisinių reikalavimų yra prieštaringi, nesuderinti tarpusavyje ir su kitais ịstatymais. Kliūtys kultūros paveldo teisinio reglamentavimo srityje neleidžia ịgyvendinti urbanistikos paveldo išsaugojimo galimybių, spartina jo fizinị nykimą ir kultūrinès vertès menkèjimą. Esant daugeliui teisinès sistemos prieštaravimų galimybès iggyvendinti apsaugos reikalavimus daugiausia priklauso nuo vietos paveldosaugos institucijų iniciatyvumo.

3. Nors pastaraisiais metais Lietuvoje privalomai pradèta rengti daug urbanistikos paveldo vietovių apsaugos specialiojo planavimo dokumentų, teisinès teritorijų planavimo galimybès nepakankamai naudojamos kaip veiksminga priemone šių teritorijų kultūrinei 
vertei stiprinti. Svarbūs apsaugos trukdžiai yra fundamentinių urbanistikos paveldo tyrimų trūkumas ir tai, kad nevykdoma sisteminè urbanistikos paveldo pokyčių stebėsena.

4. Istorinių miestelių vertingųjų savybių išsaugojimo galimybę menkina dezurbanizacija, gyventojų senèjimas. Vietos bendruomenių teisinès galimybès dalyvauti saugant Lietuvos urbanistikos paveldą yra ribotos, menkesnès nei dabartinëje teritorijų planavimo sistemoje. Skandinavijos šalių patirtis galètų tapti pavyzdžiu, kaip miestelių gyventojus galima įtraukti i urbanistikos paveldo apsaugos stiprinimą.

\section{Literatūra}

Buivydas, R. 2004. Vilniaus senamiestis: semantinis gamtos elementų vaidmuo, Urbanistika ir architektūra XXVIII(1): $18-24$.

Dèl Lietuvos Respublikos Aplinkos ministro 2004 m. gegužès 7 d. ịsakymo Nr. D1-263 „Dèl apskrities teritorijos bendrojo (generalinio) plano rengimo, savivaldybès teritorijos bendrojo plano rengimo ir miestu ir miesteliu bendruju planų rengimo taisyklių patvirtinimo" pakeitimo. 2006 m. gruodžio 14 d. Nr. D1-591 (Žin., 2006, Nr. 145-5559) [interaktyvus] [žiūreta 200811 21]. Prieiga per internetą: <http://www3.lrs.lt/pls/inter3/dokpaieska.showdoc_l?p_ $\mathrm{id}=289973 \&$ p_query=\&p_tr2=>.

Dèl nekilnojamojo kultūros paveldo apsaugos specialiojo teritorijų planavimo dokumentų rengimo taisyklių patvirtinimo 2005 m. birželio 23 d. Nr. IV-261/D1-322 (Žin., 2005, Nr. 81-2973, str. 6.1.) [interaktyvus] [žiūrèta 200811 18]. Prieiga per internetą:<http://www3.lrs.lt/pls/inter3/dokpaieska.showdoc_l?p_id=259135\&p_query=\&p_tr2=>.

Glemža, J. 2000. Paminklosaugos raida Lietuvoje, iš Kultūros paminklai 7 [interaktyvus] [žiūrèta 200811 15]. Prieiga per internetą: $<$ http://www.asa.lt/cgi-bin/str1.cgi?grp=56>.

Lietuvos Respublikos Vyriausybès nutarimas „Dèl Lietuvos Respublikos architektūros politikos krypčiu ịgyvendinimo 2006-2010 metų priemonių patvirtinimo“ (Žin., 2006, Nr. 75-2861, str. 1.14.) [interaktyvus] [žiūrèta 200811 19]. Prieiga per internetą: <http://www3.lrs.lt/pls/inter3/dokpaieska.showdoc_l?p_id=279522\&p_query=\&p_tr2=>.

Lietuvos Respublikos nekilnojamụjų kultūros vertybių apsaugos ịstatymo pakeitimo ịstatymas. $2004 \mathrm{~m}$. rugsèjo $28 \mathrm{~d}$. Nr. IX-2452 (Žin., 1995, Nr. 3-37; 1997, Nr. 30- 713, Nr. 67-1676, Nr. 96-2421; 2000, Nr. 40-1114; 2001, Nr. 39-1346; 2002, Nr. 68-2775, Nr. 123-5552) [interaktyvus] [žiūrèta 20081125 ]. Prieiga per internetą: $<$ http://www3.lrs.lt/pls/inter3/dokpaieska.showdoc_l?p_ $\mathrm{id}=197709 \&$ p_query=\&p_tr2=>.

Lietuvos Respublikos Valstybinès kultūros paveldo komisijos sprendimas „Dèl Lietuvos Respublikos apskričių teritorijų bendrųjų planų ir kultūros paveldo aspektų igyvendinant Lietuvos Respublikos teritorijos bendrąji planą“. $2008 \mathrm{~m}$. lapkričio $14 \mathrm{~d}$. [interaktyvus] [žiūrèta 200811 06]. Prieiga per internetą: $<$ http://www2.lrs.lt/kt_inst/pamink/dokumentai/2008_11_14/BendPlanai.doc $>$.
Listing. Historic buildings. Demark's Cultural Heritage. The Heritage Agency of Denmark. 2008 [interaktyvus] [žiūrèta 200812 02]. Prieiga per internetą: <http://www.kulturarv. $\mathrm{dk} /$ english/cultural_heritage/buildings/listing.jsp $>$.

Miškinis, A. 2005. Lietuvos urbanistikos paveldas ir jo vertybes. Rytu Lietuvos miestai ir miesteliai. II knyga. Vilnius: Savastis.

Miškinis, A. 2003. Šiaurès Lietuvos urbanistikos paveldas, Žiemgala 2003(2) [interaktyvus] [žiūrèta 200811 15]. Prieiga per internetą: $<w w w . z i e m g a l a . l t / z / 2003 \_02 \_02$. html>. ISSN 1648-7230.

Westerlind, A. M. 2005. Sustainable Historic Towns - Activities in Sweden, Presentation of the Pilot Town Ystad [interaktyvus] [žiūrèta 200812 05]. Prieiga per internetą: <http:// www.cmm.pl/1stCHFpdf/pdf_articles/4.2_Westerlind. pdf>.

World Heritage Site Quedlinburg. Heritage at Risk 2004/2005, in ICOMOS World Report 2004-2005 on monuments and sites in danger [interaktyvus] [žiūrèta 200812 05]. Prieiga per internetą: <http://www.international.icomos.org/risk/2004/ germany2004.pdf $>$.

\section{LEGAL PRECONDITIONS OF URBAN HERITAGE PRESERVATION IN LITHUANIA}

\section{J. Jurevičienè}

Abstract. The paper discusses urgent problems of urban heritage assesment and treatment in Lithuania today. Contradictions in the system of listing, lack of fundamental investigations, indeterminate responsibility of authorities, inadequate role of local communities are revealed as the basic factors of low efficiency of urban heritage preservation.

The most efficient means of urban heritage preservation are revealed in protected national and regional parks. Historic towns and villages of these areas remain more authentic than registered urban heritage sites in the other territories of Lithuania. The initiative of local administrations could also be considered as one of the most important factors in urban heritage preservation.

Scandinavian experience in the protection of urban heritage reveals the importance of local inhabitants in the processes of historic town preservation. Recent international documents on cultural heritage protection and changes in the Lithuanian urban planning system enable perfection of urban heritage preservation. The launched reimbursement of expenses for restoration works in Lithuania shows positive changes in this field.

Keywords: urban heritage, listing of cultural heritage, territorial planning, society.

\section{JŪRATE் JUREVIČIENE்}

Dr (architecture) (2006), Prof, Dept of Fundamentals and Theory of Architecture, Vilnius Gediminas Technical University (VGTU), Pylimo g. 26/Traku g. 1, LT-01132 Vilnius, Lithuania.

Research interests: urban heritage preservation, territory planning, cultural landscape, local architectural traditions. 